\title{
Project-based learning in integrated science education: Active teachers' perceptions and practices
}

\section{Outi Haatainen and Maija Aksela}

The Unit of Chemistry Teacher Education, Department of Chemistry, Faculty of Science, University of Helsinki, Finland

Project-based learning (PBL) is a promising teaching method for integrated science education that has gained momentum in educational research and curriculum reforms, especially as a method to enhance 21st century skills and connected worldview. How teachers implement PBL greatly affects students' content understanding and development of skills. The purpose of this qualitative study is to highlight active teachers' PBL practices and their perceptions of the advantages and challenges of implementing PBL to better promote the implementation of PBL in teacher education programs and in integrated science education. This study consisted of two parts: (1) a qualitative-led survey and (2) a case study. First, the data for the survey was collected from January to March 2017 through an online reporting form of an international StarT programme. This programme supports the implementation of interdisciplinary and collaborative PBL in science, mathematics and technology education. 244 teachers from early childhood education to upper secondary school participated from 28 countries. Second, 12 PBL units reported by the teachers were chosen for a case study. The teachers exploited PBL practices that were theme- and inquiry-based, collaborative and engaging to students. However, closer inspection revealed variation and defects in the practices particularly in relation to assessment, using reflection and student-centred approach. In addition, teachers reported several challenges relating to the implementation of PBL. The results indicate that teachers see PBL as beneficial but need support with the implementation. Science teachers' pedagogical competence in PBL could be promoted through collaborative learning in which students, teachers and other participants are learning from each other.

Keywords: project-based learning, science education, teachers' practices, STEAM

1 Introduction

Project-based learning (PBL) has a lot of potential to enhance $21^{\text {st }}$ century skills and engage students in real-world tasks (e.g. Bell, 2010; Han et al., 2015; Kingston, 2018). It promotes interconnected worldview, links among disciplines and presents an expanded view of subject matter (Blumenfeld et al., 1991; Kingston, 2018). Therefore, PBL is a promising teaching method for integrated science education that can be defined as an effort to organize or integrate science curriculum content into a meaningful whole by a constructive and context-based approach that crosses subject boundaries and links learning to real world (Åström, 2008; Beane, 1997; Czerniak \& Johnson, 2014). Integrated science education has traditionally meant integration with 
mathematics, and/or technology, such as STS (science-technology-society) or STEM (science-technology-engineering-mathematics) education (Bennett et al., 2007; Czerniak \& Johnson, 2014). In recent years, there has been an increase in discussion of a wider approach to integrated science curriculum by including other discipline areas, for example, a move to STEAM education by including the Arts to STEM (Lyons, 2020).

The successful implementation of PBL in a classroom is dependent on teacher's ability to effectively motivate and guide students' learning (Kokotsaki et al., 2016) as well as on teacher's understanding of the criteria for effective PBL (Han et al., 2015). In relations to integrated science education, there exists evidence that when PBL is implemented and instructed properly by teachers, students' learning increases, whereas teachers who ineffectively implement PBL have a negative effect on students' learning (Han et al., 2015; Kingston, 2018). However, the lack of a uniform vision of PBL complicates efforts to determine the fidelity of a PBL unit and to evaluate its effects (Condliffe et al., 2017; Hasni et al., 2016). This imposes a concern as many current national curricula (Finnish National Agency for Education [EDUFI], 2016; National Research Council, 2013) are urging teachers to implement more integrated and inquiry-based approaches, such as PBL (Hasni et al., 2016). How are science teachers supposed to assess the quality of their implementation or to know how to improve their practices, if there is no consensus on what a PBL approach in integrated science education should look like?

The purpose of this study is to describe teachers' perceptions and practices of PBL to understand how it can be implemented with fidelity as an integrated approach to science education. The teachers participating in this study are considered active and motivated to develop their teaching as they have voluntarily taken part in the international StarT programme (LUMA Centre Finland, n.d.), which supports the implementation of interdisciplinary and collaborative PBL in science, mathematics and technology education. 


\section{Theoretical background}

\subsection{Project-based learning}

Project-based learning (PBL) is a student-driven, teacher-facilitated pedagogical approach that organizes learning around clearly defined projects (Han et al., 2015; Kokotsaki et al., 2016; Thomas, 2000). PBL has roots in constructivist theories of learning: learning is context-specific, learners actively construct their understanding by engaging in meaningful real-world issues, and they achieve their goals through social interactions and sharing of knowledge and understanding (Kokotsaki et al., 2016; Krajcik \& Shin, 2014; Savery, 2019).

Similar instructional strategies exist such as problem-based learning, inquirybased learning and "Learning by Design" (Savery, 2019), and there is some debate in the literature, especially about the distinction between project- and problem-based learning. Scholars acknowledge that the two concepts have different histories (Condliffe et al., 2017), but have argued for seeing problem-based learning as a type of project-based learning (Boss \& Larmer, 2018; Thomas, 2000). On the contrary, Savery (2019) argued that it is important to clarify the differences between the two concepts since, unlike problem-based learning, project-based learning requires constructing a concrete artefact as an answer to the driving problem or a question.

Many attempts have been made to clarify the PBL design principles that describe the essential components of a PBL approach. There exist a wide agreement that PBL is a process of learning; including activities and inquiry that results in artefacts or final products that address the driving question or a problem set at the beginning (Blumenfeld et al., 1991; Boss \& Larmer, 2018; Condliffe et al., 2017; Thomas, 2000). However, there is still no consensus on what constitutes PBL (Condliffe et al., 2017). For example, PBL can be emphasized as interdisciplinary (e.g. Han et al., 2015) or according to others (e.g. Savery, 2019) projects may also be disciplinary specific. Furthermore, it is unclear whether PBL design principles should address the content of learning, to what extent students' choice or collaboration needs to be included in PBL approach or how learning should be assessed (Condliffe et al., 2017). In Table 1 is a synthesis on design principles adapted from three reviews (Condliffe et al., 2017; Kokotsaki et al., 2016; Savery, 2019) discussing the issue and with recommendations for the essential elements to be considered when designing and implementing PBL. 
Table 1. The project-based learning (PBL) design principles adapted from Condliffe et al. (2017), Kokotsaki et al. (2016) and Savery (2019).

\begin{tabular}{|c|c|}
\hline Element & Description \\
\hline $\begin{array}{l}\text { Student } \\
\text { learning } \\
\text { goals }\end{array}$ & $\begin{array}{l}\text { The content of a PBL curriculum or study unit that ensures the successful implementation } \\
\text { of PBL as a part of science teaching. The project should be focused on teaching students (1) } \\
\text { key concepts and understanding derived from national curriculum or standards, and ( } 2 \text { ) } \\
\text { subject matter content as well as } 21^{\text {st }} \text { century skills (e.g. critical thinking, problem solving, } \\
\text { collaboration and self-management). }\end{array}$ \\
\hline $\begin{array}{l}\text { Centrality of } \\
\text { the project }\end{array}$ & $\begin{array}{l}\text { This feature distinguishes PBL from other instructional approaches: project is not the } \\
\text { culmination of learning as it often is in standard classrooms, but instead in PBL approach } \\
\text { the project is seen as a process through which learning takes place. }\end{array}$ \\
\hline Context & $\begin{array}{l}\text { Projects should be authentic, meaningful, related to a real-world context or an important } \\
\text { issue, and be connected to students' own concerns and interests. Furthermore, projects } \\
\text { require a well-designed and open-ended driving question or a problem, at the appropriate } \\
\text { level of challenge for students, that serves to organize all the project activities. }\end{array}$ \\
\hline $\begin{array}{l}\text { Project } \\
\text { artefact }\end{array}$ & $\begin{array}{l}\text { Project activities should involve the creation of a final tangible product that addresses the } \\
\text { driving question and offers representation of students learning. }\end{array}$ \\
\hline Collaboration & $\begin{array}{l}\text { PBL requires social negotiation of knowledge, working collaboratively in groups, to develop } \\
\text { possible solutions to the project. Collaboration should be a feature of all project stages. }\end{array}$ \\
\hline $\begin{array}{l}\text { Construction } \\
\text { of } \\
\text { knowledge }\end{array}$ & $\begin{array}{l}\text { PBL involves students in a process of constructing knowledge. This can be achieved } \\
\text { through in-depth inquiry, critical thinking, the use of problem-solving, and by revision of } \\
\text { what is currently known and what needs to be understood before proceeding. }\end{array}$ \\
\hline $\begin{array}{l}\text { Student } \\
\text { engagement }\end{array}$ & $\begin{array}{l}\text { Teachers should foster student engagement from the beginning of the project to the end. } \\
\text { Students' freedom to generate project artefacts and their active participation is vital for } \\
\text { the construction of knowledge. Although encouraging student choice align with student- } \\
\text { centred approaches, it is not explicitly clear what the extent of student autonomy should } \\
\text { be in a PBL unit. }\end{array}$ \\
\hline $\begin{array}{l}\text { Scaff } \\
\text { instr }\end{array}$ & $\begin{array}{l}\text { Scaffolding instruction refers to any method or a resource (e.g. teachers, peers, learning } \\
\text { materials and technologies) used by teachers to help learners to accomplish more difficult } \\
\text { tasks than they otherwise are capable of completing on their own. Two key elements of } \\
\text { scaffolding: (1) scaffolds need to be tailored to a student's current level of understanding } \\
\text { and (2) scaffolds should be faded over time as students learn to apply their new knowledge } \\
\text { or skills on their own. }\end{array}$ \\
\hline Assessment & $\begin{array}{l}\text { Emphasis should be on formative assessment that aims at supporting students learning. } \\
\text { This includes reflection, self and peer evaluation, and teachers' feedback throughout the } \\
\text { project process. Assessment should include a specific end-of-project phase that ensures } \\
\text { reflection on what was learned as well as the creation of a project artefact. }\end{array}$ \\
\hline Publicity & $\begin{array}{l}\text { A public presentation of the project supports students' communication skills, can motivate } \\
\text { students, and presents an opportunity for feedback. Instead of a presentation, the product } \\
\text { itself can be public. This element includes the PBL criterion of authenticity. }\end{array}$ \\
\hline
\end{tabular}




\subsection{PBL in integrated science education}

PBL has a lot of potential to enhance $21^{\text {st }}$ century skills and engage students in realworld tasks (Bell, 2010; Han et al., 2015; Kingston, 2018). The $21^{\text {st }}$ century skills or transversal competences (EDUFI, 2016) are common denominators for various skills necessary for success in daily life, such as critical thinking, problem-solving, collaboration, communication, and self-management skills (EDUFI, 2016; Viro \& Joutsenlahti, 2020). Of these skills, for example, problem-solving is closely linked to mathematics and inquiry is an essential part of science education. However, skills alone are not enough as objectives of a PBL unit in integrated science education; students need to develop their knowledge and understanding of the key concepts of science, mathematics and other integrated subjects (Viro \& Joutsenlahti, 2020). Research evidence indicates that PBL can promote student learning in acquiring deeper content knowledge and skills in science and mathematics (Condliffe et al., 2017; Kingston, 2018; Viro \& Joutsenlahti, 2020). In addition, some studies have reported increased attendance, self-reliance, and improved attitudes towards learning on the part of students (Kingston, 2018; Thomas, 2000). Furthermore, evidence suggests that teachers regard PBL as beneficial for both teachers and students (Condliffe et al., 2017).

Researchers have identified common implementation challenges that relate to the design principles of PBL. These include teachers' knowledge, skills and attitude related issues such as (1) teachers' resistance to student-centred learning, (2) confusing inquiry-based instruction with hands-on activities, (3) inability to motivate students to work in collaborative teams, (4) scaffolding instruction, and (5) the development of authentic assessment (Condliffe et al., 2017; Mentzer et al., 2017; Viro et al., 2020). Furthermore, melding required curriculum with PBL is one of the most important but difficult aspects of designing a project-based approach (Condliffe et al., 2017). Other challenges relate to students' resistance to employing critical thinking (Mentzer et al., 2017), unsatisfactory group working (Condliffe et al., 2017), lack of motivation (Condliffe et al., 2017; Marshall et al., 2010) and readiness for studentcentred approaches in integrated science education (Han et al., 2015). In addition, teachers struggle with time constraints and inadequacy of resources to support indepth student investigations needed for constructing knowledge (Condliffe et al., 2017; Viro et al., 2020).

Externally developed PBL curricular units for science education, such as ProjectBased Inquiry Science (Kolodner et al., 2015) and Investigating and Questioning our 
World through Science and Technology (Shwartz et al., 2008), have been developed in recent years to answer the challenges. Both were inspired by the project-based science design principles of Blumenfeld et al. (1991) and Krajcik and Shin (2014), which emphasize driving questions, collaborative student-led inquiry, the use of technology to scaffold student learning, and the creation of authentic artefacts. The common thread of PBL elements that runs through these two middle school science curricula demonstrates the importance of connecting concepts, research, and practice (Condliffe et al., 2017; Kolodner et al., 2015; Shwartz et al., 2008). However, the externally developed curricula can be overly prescriptive, and most teachers do not have access to them (Condliffe et al., 2017). As a result, PBL continues to be mostly designed and implemented by teachers on their own.

Teachers' self-perception and conceptualization of teacher roles have a fundamental impact on teachers' implementation of PBL (Habók \& Nagy, 2016). Han et al. (2015) state that teachers' role in implementing STEM related PBL must differ from the traditional classrooms. Changing teachers' beliefs about their role in a classroom from that of director to facilitator is one of the main implementation challenges for student-centred pedagogical approaches like PBL (Ertmer \& Simons, 2006). In addition, teachers' beliefs about their students' potential can also influence PBL implementation (Condliffe et al., 2017). In relation to integrated science education, the evidence suggests that teachers' understanding and implementation of PBL affects learning outcomes (Han et al., 2015; Kingston, 2018).

Viro et al. (2020) investigated teachers' views on PBL in mathematics and science. The results were somewhat varied. The development of teamwork skills and the connection between theory and practice were both deemed highly important characteristics of PBL. Other elements of PBL, that teachers perceived positively, were its contribution to students' motivation and mathematics learning. However, teachers expressed contradictory views on PBL: (1) it was irrelevant for mathematics, and (2) it hinders organizing, scheduling and teamwork. Furthermore, teachers perceived PBL negatively because it was an unfamiliar method to them (Viro et al., 2020). 


\section{Methodology}

The main question that guided this qualitative study from the start was: How can PBL be implemented in integrated science education? This question was further divided into three sub-questions:

1. What are teachers' perceptions on the advantages of implementing PBL?

2. What are teachers' perceptions on the challenges of implementing PBL?

3. What kind of elements of PBL are incorporated in teachers' practices reported to the StarT programme?

The study consists of two parts. First, a qualitative-led survey (Braun et al., 2017) was administered through an online reporting form of the StarT programme. Second, a case study (Cohen et al., 2007) was made to have a more in-depth understanding of teachers' practices reported to the StarT programme.

\subsection{Context of the study}

StarT is an international programme organized annually by LUMA Centre Finland and for the first time in the 2016-2017 school year. The aim of StarT is to support integrated science, mathematics and technology education by collaborative PBL from early childhood education to upper secondary school. The PBL approach of StarT includes broad themes (e.g. Mathematics around us, Nature and environment, Wellbeing, and Stars and space) to help teachers and students focus their project activities. There are five requirements and a recommendation for StarT projects:

1. The project is multidisciplinary and linked to science, mathematics or technology.

2. The project is carried out in a team of students.

3. The project is a product of the students' work, showing their expertise and making use of their own interest and creativity.

4. The project includes a learning diary that outlines what students have learned during the project.

5. The project results in a final artefact that is visualized by a short video.

6. It is recommended that students are given a chance to present their project publicly. In addition, project descriptions, videos and diaries are published as examples on the webpage of StarT. 
In other respects, the StarT programme gives teachers autonomy to design their own PBL units (e.g. the form of the artefact, the length of the project or the subjects to be incorporated).

\subsection{Data collection}

Data was collected from January to March 2017 through the StarT online reporting form in Finnish and in English. The participants are considered active teachers who are motivated to develop their teaching, as they have voluntarily taken part in the international StarT programme and designed and implemented their own PBL unit in science, mathematics and technology education. For StarT programme, participants were asked to report PBL practices and activities implemented during 2016 or 2017. In addition, participating teachers were asked to answer the survey questionnaire. Out of 275 teachers, 244 participated in the research: 99 Finnish teachers and 145 teachers from 27 other countries, mainly from Europe. Teachers represented various levels of education, from early childhood education to upper secondary schools. Teacher distribution, according to the taught level of education, for Finnish teachers was $13 \%$ in early childhood education, $57 \%$ in primary schools, $24 \%$ in secondary schools and $6 \%$ in upper secondary schools. The taught level of education was lacking in many reports of international teachers.

Based on the reports, twelve PBL units were chosen for the case study to examine how the design principles of PBL were incorporated in teachers' practices. The data included project descriptions, videos, photographs, and diaries as well as teachers' descriptions of their practices related to carrying out StarT projects. The selection of cases was done according to two criteria: 1) the PBL unit had a comprehensive report and 2) the sample would include various project examples with different StarT themes and from different education levels and countries. A short description of the chosen cases is given in Table 2. 
Table 2. The twelve project-based learning (PBL) units included in the case study. Description includes the country, the level of education, the StarT theme, the length of the PBL unit and the number of projects done by student groups.

\begin{tabular}{|c|c|c|c|c|c|}
\hline CASE & Country & Level of education & $\begin{array}{l}\text { Number } \\
\text { of } \\
\text { projects }\end{array}$ & StarT theme & Length of the PBL unit \\
\hline 1 & Lithuania & $\begin{array}{l}\text { Primary school (4th } \\
\text { grade) }\end{array}$ & $1-5$ & $\begin{array}{l}\text { Everyday } \\
\text { mathematics }\end{array}$ & $\begin{array}{l}\text { Time spent on project was } \\
\text { spread across the school } \\
\text { year }\end{array}$ \\
\hline 2 & Indonesia & $\begin{array}{l}\text { Lower secondary } \\
\text { school (8th grade) }\end{array}$ & $1-5$ & $\begin{array}{l}\text { Technology } \\
\text { around us }\end{array}$ & 4 weeks \\
\hline 3 & Greece & $\begin{array}{l}\text { Lower secondary } \\
\text { school }\end{array}$ & $1-5$ & $\begin{array}{l}\text { Programming } \\
\text { and robotics }\end{array}$ & Not specified \\
\hline 4 & Romania & $\begin{array}{l}\text { Upper secondary } \\
\text { school }\end{array}$ & $6-10$ & $\begin{array}{l}\text { Stars and } \\
\text { space }\end{array}$ & Not specified \\
\hline 5 & Portugal & $\begin{array}{l}\text { Upper secondary } \\
\text { school }\end{array}$ & $6-10$ & Well being & $\begin{array}{l}\text { From December } 2016 \text { to } \\
\text { March } 2017\end{array}$ \\
\hline 6 & Turkey & $\begin{array}{l}\text { Upper secondary } \\
\text { school (16-year-old) }\end{array}$ & $1-5$ & $\begin{array}{l}\text { Nature and } \\
\text { environment }\end{array}$ & Not specified \\
\hline 7 & Spain & Secondary school & $1-5$ & $\begin{array}{l}\text { Everyday } \\
\text { mathematics }\end{array}$ & Not specified \\
\hline 8 & Hungary & $\begin{array}{l}\text { From early childhood } \\
\text { education to } \\
\text { secondary schools }\end{array}$ & $1-5$ & $\begin{array}{l}\text { Nature and } \\
\text { environment }\end{array}$ & A week, working daily \\
\hline 9 & Belgium & $\begin{array}{l}\text { Primary school (5th } \\
\text { grade) }\end{array}$ & $1-5$ & $\begin{array}{l}\text { Programming } \\
\text { and robotics }\end{array}$ & $\begin{array}{l}\text { Six or seven 'sessions' } \\
\text { during a month }\end{array}$ \\
\hline 10 & Finland & $\begin{array}{l}\text { Primary school (5th } \\
\text { grade) and lower } \\
\text { secondary school }\end{array}$ & $1-5$ & $\begin{array}{l}\text { Stars and } \\
\text { space }\end{array}$ & $\begin{array}{l}\text { Time spent on project was } \\
\text { spread across the school } \\
\text { year }\end{array}$ \\
\hline 11 & Finland & $\begin{array}{l}\text { Lower secondary } \\
\text { school (9th grade) }\end{array}$ & $1-5$ & $\begin{array}{l}\text { Nature and } \\
\text { environment, } \\
\text { Technology } \\
\text { around us }\end{array}$ & $\begin{array}{l}\text { Two or three lessons (45 } \\
\text { minutes) per integrated } \\
\text { subject; approximately } 10 \\
\text { lessons }\end{array}$ \\
\hline 12 & Lithuania & $\begin{array}{l}\text { Upper secondary } \\
\text { school }\end{array}$ & over 15 & $\begin{array}{l}\text { Everyday } \\
\text { mathematics }\end{array}$ & $\begin{array}{l}\text { Multiple project events } \\
\text { organized during the } \\
\text { school year }\end{array}$ \\
\hline
\end{tabular}




\subsection{Data analysis}

As the aim of this study is to explore and understand how PBL can be implemented in integrated science education, a qualitative content analysis (Drisko \& Maschi, 2015; Mayring, 2014) was chosen as an analysis method both for the qualitative-led survey and the case study.

A qualitative content analysis with an explorative design (Mayring, 2014) was used in the survey. It included a data-based, inductive category formation of teachers' ( $n=244$ ) answers to open-ended questions mapping, (1) teachers' experiences with PBL in StarT, (2) teachers' perceptions of the main advantages of implementing PBL, and (3) teachers' perceptions of the main challenges of implementing PBL. Teachers' answers were first coded with a partial sample (99 Finnish teachers) and tested with two inter-raters. Cohen's kappa coefficient was chosen to test the reliability as it is used for assessing agreement between two raters on a nominal scale. Once the reliability was considered good ( $>0.60$ ), the coding was done for the whole sample. The material not relevant for answering the research questions were omitted from the analysis. The final inter-coder reliability was $\mathrm{k}=0,79$ for the categories of advantages of PBL and $\mathrm{k}=0,82$ for the challenges of PBL.

The analysis technique followed in the case study was an interpretive, theorydriven content analysis (Drisko \& Maschi, 2015; Mayring, 2014). It aimed at describing the elements of PBL incorporated in the 12 PBL units chosen as cases (see Table 2). An effort was made to ensure reliability of the case study through a careful analysis of the versatile data reported by teachers, and by checking the intra-coder reliability throughout the analysis process. The reliability could be improved by an inter-coded reliability.

\section{Results}

\subsection{Advantages of PBL in practice}

Teachers viewed PBL as having multiple advantages that are shown in Table 3. Especially, teachers $(60,7 \%)$ valued PBL for its possibilities for learning. Often these answers referred to learning in general such as "we learned a lot more than we initially thought we would" (teacher F3), or the answers related to students' increased skills (e.g. group working, social interaction and problem-solving skills) as well as to students learning how to use equipment or programs; often related to making videos. Fewer comments related to the learning of subject content knowledge, and only a 
couple of teachers mentioned students having a more interconnected view as a learning advantage. Mostly learning was regarded from student's point of view, but in some instances learning included everyone involved in the project, students and teachers alike.

Table 3. Teachers' views on the advantages of project-based learning (PBL).

\begin{tabular}{lcccccc}
\hline Advantages of PBL & \multicolumn{2}{l}{ Teachers } & & & \multicolumn{2}{c}{} \\
& \multicolumn{2}{c}{ Finnish (99) } & \multicolumn{2}{c}{ Other (145) } & \multicolumn{2}{c}{ All (244) } \\
\cline { 2 - 7 } & $\mathrm{n}$ & $\mathrm{n} \mathrm{( \% )}$ & $\mathrm{n}$ & $\mathrm{n}(\%)$ & $\mathrm{n}$ & $\mathrm{n}(\%)$ \\
\hline Learning outcomes & 62 & 62,6 & 86 & 59,3 & 148 & 60,7 \\
$\quad$ Skills & 37 & 37,4 & 43 & 29,7 & 80 & 32,8 \\
$\quad$ Increased awareness & 2 & 2,0 & 27 & 18,6 & 29 & 11,9 \\
\hline Collaboration & 57 & 57,6 & 74 & 51,0 & 131 & 53,7 \\
\hline Motivation & 56 & 56,6 & 41 & 28,3 & 97 & 39,8 \\
\hline Student-centredness & 47 & 47,5 & 44 & 30,3 & 91 & 37,3 \\
\hline Versatility for education & 36 & 36,4 & 49 & 33,8 & 85 & 34,8 \\
\hline
\end{tabular}

Many teachers (53,7\%) valued collaboration and a sense of community generated by the practice. Collaboration with other teachers or classes was found useful in practice:

More experienced teachers oriented the less experienced teachers and always supported them. (Teacher I29)

Projects unified the whole school and added communality and "we" atmosphere. (Teacher F2)

Collaboration between classes of different age students was enjoyable and important. (Teacher F24)

In addition, the wider collaboration possibilities offered by StarT or collaboration with other interest groups were found fruitful as a support for implementation or because of the opportunities for public presentation of the projects:

The idea [of StarT] is interesting because it is an opportunity for our high school to highlight our activities and share them with others. (Teacher I2)

Belonging to a bigger unity has given structure to our project. The educators have had an opportunity to get peer support and ideas to own project. (Teacher F103)

Students demonstrated their work to their parents. The parents are proud of them. (Teacher I21) 
The greatest experience was that the students have learned to work in teams not only with mates but also with parents, grandparents, teachers. (Teacher I84)

Kids share their knowledge and tell everyone (to friend, father or mother, kids from other class and all schools community) about their project and what they have learned during this StarT project. (Teacher I52)

Some reported collaboration as a benefit because it created more joy or positive attitudes that can have an effect on the motivation of students and teachers. This was evident in the answers highlighting motivation as the main benefit. Motivational aspects of PBL related to positive attitude change, building self-esteem, relevance, enthusiasm and getting excited or engaged in project working. Most answers related to enthusiasm.

The enthusiasm for project-based work was very infectious and initiated an actual snowball effect as the idea to pick Aronia berries for juice developed into a diverse market day! (Teacher F11)

In the student-centred learning category, most cases were about students being active learners. In addition, comments related to group working and taking different learners or students' interests into account. Versatility in education was a more heterogenic category compared to the others. This category included all cases with new possibilities for implementing curriculum and using versatile teaching methods and learning environments.

Finnish teachers' views differed somewhat from the teachers in other countries. Finnish teachers regarded the student-centred nature of PBL as one of the main benefits or even the most useful element of PBL, whereas a minority of teachers from other countries mentioned this element as a benefit. On the contrary, they seemed to view the usefulness more from the perspective of teaching and regarded the versatility of education as one of the main benefits. 


\subsection{Challenges of the PBL in practice}

Teachers' views on the challenges (see Table 4) of implementing PBL were more coherent than views on the advantages of PBL.

Table 4. Teachers' views on the challenges of implementing project-based learning (PBL).

\begin{tabular}{|c|c|c|c|c|c|c|}
\hline \multirow[t]{3}{*}{ Challenges of PBL } & \multicolumn{6}{|c|}{ Teachers } \\
\hline & \multicolumn{2}{|c|}{ Finnish (99) } & \multicolumn{2}{|c|}{ Other (145) } & \multicolumn{2}{|c|}{ All (244) } \\
\hline & $\mathrm{n}$ & $\mathrm{n}(\%)$ & $\mathrm{n}$ & $\mathrm{n}(\%)$ & $\mathrm{n}$ & $n(\%)$ \\
\hline Facilitating PBL & 62 & 62,6 & 81 & 55,9 & 143 & 58,6 \\
\hline Time management & 33 & 33,3 & 26 & 17,9 & 59 & 24,2 \\
\hline Project facilitation & 30 & 30,3 & 51 & 35,2 & 81 & 33,2 \\
\hline Teachers skills & 12 & 12,1 & 9 & 6,2 & 21 & 8,6 \\
\hline \multicolumn{7}{|l|}{ Structural issues } \\
\hline Technical & 35 & 35,4 & 16 & 11,0 & 51 & 20,9 \\
\hline Resources & 26 & 26,3 & 10 & 6,9 & 36 & 14,8 \\
\hline \multicolumn{7}{|l|}{ Interactional issues } \\
\hline Student-related & 23 & 23,2 & 30 & 20,7 & 53 & 21,7 \\
\hline Collaboration & 20 & 20,2 & 10 & 6,9 & 30 & 12,3 \\
\hline
\end{tabular}

Facilitating PBL was considered the main challenge in most responses. Besides facilitating the project work, this included notions relating to time management or laborious planning. In addition, responses were linked to teachers' self-efficacy or their perceived skills to facilitate PBL, even if this was not explicitly voiced.

Believing in yourself [was a challenge for me]. I took this as a big challenge to experience and learn something new and I exposed myself to learning a new teaching method. (Teacher F9o)

Doing [projects] raises feelings of insecurity on whether this is away from something important and have we fulfilled the subject content required by curriculum. The most difficult part was to manage the time. We had lots of thoughts to discuss and sort out the information to improve and get the best project in two months. (Teacher I99)

Technical issues include not only the challenges faced with using different technological tools, but also issues with the documentation for StarT such as "making video with non-existent ICT skills" (Teacher F30). The second structural issue related to resources or the lack there of; mainly teachers were lacking space, ICT equipment and time. 
Student-related challenges revealed that teachers were having motivational issues with students, as either it was difficult "getting different learners engaged into active learning and working" (Teacher F34), or students were so engaged that they "were working much more than was needed to fit into the curriculum" (Teacher I152). In some cases, students lost their interest during the project work, as was reported by Teacher F71: "The schedule was too heavy, and some students got tired and started to go it alone. It has taken the time of the adults involved in the project to motivate these students shirking their duties." Furthermore, teachers reported issues with scaffolding instructions "in balanced proportions, so that you don't restrict students too much but give opportunities and offer tools" (Teacher F52) and with students' inadequate skills and knowledge.

The most challenging was to find suitable action that suited the students' skills. (Teacher F35)

The most challenging part of our project was that it took time for the students to realize their potential because they had never taken part in similar projects before. (Teacher I13)

Working in pre-set groups is not easy for everybody. (Teacher F55)

Possibilities for collaboration were reported as limited, mainly because teachers had trouble with finding the time for planning with colleagues.

Overall, Finnish teachers reported more challenges with collaboration, time management and technical issues than teachers from other countries. Language was not a challenge to Finnish teachers. However, this most likely is because Finnish teachers could report in Finnish or Swedish. Teachers from other countries all reported in English.

\subsection{Teachers' PBL practices}

Teachers' practices analysed in this study seemed initially to meet most of the PBL design principles. All projects featured the elements specified in StarT project requirements. However, in closer inspection, the variation and shortcomings of the implementations became evident. The overall results are gathered in Appendix 1.

Student learning goals. Mainly the learning outcomes set for the projects related to $21^{\text {st }}$ century skills such as communication, collaboration, problem-solving and thinking skills. However, in $75 \%$ of the cases, teachers reported learning goals related 
to subject contents or cross-curricular concepts, especially socio-scientific issues (SSI).

We develop a pro-active, dynamic, open-minded attitude, valuating the creative potential and the personal experience of each individuals involved in the project (students, teachers), as well as their high order abilities and cross-curricular capacities, their learning, research, thinking, communication, cooperation, working, adaptability competences, namely the 21st century competence. (Teacher, case 4)

The main objective is to study the mathematical properties of the mosaics (tessellations of the plane), in addition to the way in which they have been constructed (using twirls, symmetries, translations, ...). (Teacher, case 7)

Centrality of the project. All reported practices and projects had elements indicating PBL being viewed as a learning process rather than a simple project product to indicate previously learned. Some teachers specified the process steps and others emphasized the link between project practice and subject content in design. However, teachers' responses were contradictory. For example, in case one the learning goal focused on skills and "applying the acquired knowledge of mathematics", indicating the project is perhaps seen more like a rehearsal. This was also a very teacher-led project: the teacher set all specific learning activities that accumulated into workshops and assignments to be used at a special event for the school and parents.

Contextual. This category was divided into three subcategories specifying how the context had been taken into account in the practices:

1. Projects that had a driving question or a problem

2. Projects based on a common theme or a topic

3. Projects linked to real-world

In most cases (11 out of 12), context was created by a theme that could be directly taken from the themes of StarT programme such as "Mathematics around us" or themes related to real-world issues such as climate change or gender equality. Less than half of the cases (5 out of 12) had set a driving question. Some questions were driven from students' interest and engaged in inquiry and investigation such as "How can we solve the problem of not being seen as a pedestrian on the dark roads?" (case 2). However, some of the driving questions were not open-ended or engaged in inquiry. For example, "Why is Mars called a red planet?" (case 3) enables copying the answer directly from Wikipedia. In this case, teachers give students the autonomy to 
choose their own questions. However, with some guidance, the question could have been revised into one that engages in inquiry and focuses the project activities towards the main goal of learning programming.

Project artefact. As it was a requirement of StarT programme, in all projects a product or products were made. These were for example booklets, posters, written reports, crafted products with electronics, videos, songs, exhibitions, and workshops for other students and parents. In most cases, students had the freedom to choose what was created. In four projects, the artefact to be created was set by the teachers in preplanning phase.

Collaborative learning. This category was divided into three subcategories to specify the nature of collaboration. In all projects, the students worked in groups, as this was a requirement of the StarT programme. 66,7 \% of the projects were interdisciplinary and included collaboration with teachers of different subjects. Furthermore, collaboration was done with other classes and different education levels as well as with experts and organizations.

Our Science Festival was called "What About Geology?"... As the teams investigated and studied the subject, the group of cicerones, with my help, drew the space that would be our festival (four in total). The collaboration of the community was essential: the city council provided transportation for kindergarten students [to the festival], the military provided and set up four tents and two large awnings, the school staff helped in the construction of some scientific models and in the placement of large structures, gym teachers assisted in the supervision... National geoparks, science centres and biosphere reserves were present; the university experts trained the students in the areas that were being investigated. (a teacher, case 5)

Constructive nature of PBL was featured in all projects except one. This was mainly concluded from the aims teachers and students had set for their working. To support the construction of knowledge, teachers' practices included for example lecturing, using assignments or mind-maps, and collaborating with experts. In many cases, projects were based on inquiry and investigations that included gathering of information from various sources. Discussions and brainstorming sessions were used within the group, with the teacher or with the whole class. Furthermore, with projects focused on building a concrete artefact, students tested possible solutions and built prototypes.

The full potential of the learning diary was not utilized, as it was evident that in most cases the diaries were written after the project was finished, therefore, serving more as reports. Only one project (case 9) clearly used the diary as a tool for reflection 
and assessment with students writing daily about the progress of the project and their group working.

Student engagement was taken into consideration in all cases. The practices varied from teacher-led projects (four out of 12), to student-centred projects (three out of 12). Most cases had elements of both with teachers setting the aims and frame for working, and students making their choices within the frame. Teachers' practices to engage and activate students included discussions, brainstorming, hands-on activities, quizzes and study visits. In addition, participation in contest and events, such as offered by StarT, can be seen as an engaging practice.

Scaffolding instructions were not specifically mentioned by teachers, but project reports included various elements of teachers' practices to support and guide student working. For example, in case four, teachers set a clear timeframe with deadlines for the students' project working, and in case twelve, a Facebook group was set up to ask questions and give project updates.

Assessment. Only a few teachers mentioned aspects of assessment in their reports. From the data gathered, it was mostly impossible to draw any conclusion about the assessment of the project.

Publicity was mentioned in the recommendations of StarT programme and all projects were presented publicly. Mainly this was done in schools with other classes, teachers, and school staff as audience, but some projects participated in local events or organized one such as an exhibition in library by themselves. Furthermore, the project products in five cases were public by nature. For example, publicly distributed videos and websites were created.

\section{Discussion}

\subsection{Teachers' perceptions of the advantages of PBL}

National curricula, standards and many researchers promote PBL as a potential method for integrated science education and for learning the $21^{\text {st }}$ century skills. The class, science and mathematics teachers participating in this study share this positive perception of the advantages of PBL. Especially for learning science and mathematicsrelated skills such as problem-solving, inquiry and critical thinking. Teachers regarded increased motivation, collaboration and educational versatility among the main advantages of PBL. These results relating to teachers' perceptions of the advantages of PBL are consistent with earlier findings (e.g. Han et al., 2015; Kingston, 
2018; Viro et al., 2020). Interestingly, few teachers mentioned as an advantage the promotion of interconnected worldview that has been highlighted in literature (Blumenfeld et al., 1991; Czerniak \& Johnson, 2014), especially in relation to PBL being an integrated approach to science education.

Finnish teachers' perception on the advantages of PBL varied from teachers from other countries. Finnish teachers regarded as a major benefit the student-centred nature of the PBL, whereas international teachers emphasized more the versatility to education. This can perhaps be explained by the nature of StarT programme, as in Finland it includes collaborative events, science and technology festivals, for both students and teachers to share their learning and practices. Whereas international StarT programme was focused on the competition.

\subsection{The PBL design principles of teachers' practices}

To have successful outcomes, PBL implementations must meet design principles (see synthesis in Table 1) that are still under some debate. This lack of a uniform vision of PBL still continues to complicate the efforts to determine the quality of a PBL unit and to evaluate its effects (Condliffe et al., 2017; Hasni et al., 2016). Results of this study indicated that teachers' PBL practices seemed to meet most of the key elements. However, in closer inspection the inadequacy and variation of the implementations became clear.

First, the amount of student autonomy varied from teacher-led activities with little student choice to complete student autonomy in relation to the execution of projects. In general, students' involvement was minimal or even absent in setting the learning aims, overall theme, schedule and assessment of the project. This raises the question whether all PBL practices meet the criteria for successful PBL in the first place, as student choice is a key element of the PBL approach (e.g. Bell, 2010; Boss \& Larmer, 2018; Kokotsaki et al., 2016).

Second, half of the cases in the case study had not set a clear driving question or a problem to focus students' inquiries and motivate learning. Instead, the PBL activities and artefact created were based on a common theme. It should be noted that the broader theme allowed in some cases more freedom for the students to choose over the direction of their own project, and it is possible students set specific questions or problems even though this was not brought out in the material teachers or students shared with the StarT programme. In any case, a clearly set driving question is argued as an essential criterion by many researchers (e.g. Blumenfeld et al., 1991; Boss \& 
Larmer, 2018; Condliffe et al., 2017) and a lack thereof can have an effect on the learning outcome.

Third, the construction of knowledge was further lacking as many projects seemed to lack the critique and revision phases. Partly this can be because of the difficulties to manage time that was mentioned by many teachers as one of the main challenges. The critique or revision was mainly done in two phases of a project process: (1) in the beginning to assess what is known and what needs to be learned, and (2) while presenting the project and artefact at the end of the project process.

Fourth, perhaps relating to the previous, only a couple of cases referred to formative assessment as being a part of the PBL unit, even though most teachers had set specific learning goals for students' projects. PBL should not merely be a supplementary activity that supports learning; the project should be central in the learning process (Boss \& Larmer, 2018; Condliffe et al., 2017; Thomas, 2000), and assessment should be formative by nature to include students' entire learning process. In addition, the full potential of project diaries as a learning aid and an assessment tool was not taken advantage of as many reported to have written the diaries after the project process, only as a part of the reporting to StarT programme. However, one should not generalize this observation, as there was not enough evidence about the assessment included in the PBL units. It is possible that teachers did not feel the need to report about their assessment to the StarT programme, as assessment was not stated in the guidelines for StarT projects nor in the assessment criteria for the StarT competition. Could it be that teachers regarded participating in StarT as being only motivational, adding versatility to their education, and not as being part of the science education curriculum? Regardless, to be feasible in science education PBL should include the learning of curriculum concepts through a project (Bell, 2010; Savery, 2019; Viro \& Joutsenlahti, 2020) and these curriculum-related contents should be included in the assessment of the project.

\subsection{Teachers' perceptions of the challenges of PBL}

Teachers' practices and professional competence for implementing PBL have an effect on the challenges teachers face while implementing PBL. Major challenges, according to this study, are facilitating PBL and the lack of time (similar to Mentzer et al., 2017). Often teachers referred as a challenge the planning time with colleagues or the timeconsuming nature of project work in general. The latter is an issue teacher can facilitate, as are many of the challenges teachers reported (see Table 3). Thorough and 
careful planning is essential to the flow of the project and the success of students (Bell, 2010). Unfortunately, teachers are reporting that they do not have sufficient time for planning, and it can have a direct effect on the implementation as well as on teachers' and students' experiences during the PBL unit.

Interestingly, Finnish teachers reported more challenges compared to teachers from other countries. Internationally, StarT is mainly a competition, and this could have had an effect on the reports by international teachers and their desire to portrait their own work in as positive light as possible. However, PBL is a new approach to Finnish teachers; can it be that their inexperience with PBL is showing in these results? On the other hand, based on the cases analysed in this study, the Finnish projects were more collaborative and student-centred, which could explain the greater amount of faced challenges. Earlier research has indicated that the culture and educational system has an influence on teachers and their teaching approaches. Further research comparing different countries, cultures and educational systems is needed to answer these questions.

\section{Conclusions}

Teachers are in a pivotal position in transferring PBL into integrated science classroom practices that are commended by many national science curricula and reforms. How teachers perceive and implement PBL greatly affects learning outcomes. The aim of this qualitative study was to explore and understand teachers' perceptions and practices. The results are based on teachers' reports to the StarT programme. Efforts were made to ensure the reliability of the results through a careful analysis of versatile data as well as checking the intra- and inter-coder reliability. However, the researchers had minimal opportunity, only through videos and photographs, to observe the actual implementations of the PBL units analysed in the case study. Even though the results cannot be generalized, they add to our understanding of teachers' perceptions of PBL and PBL design principles for integrated science education.

The results of this study indicate that teachers have a general idea of PBL and its advantages. Nevertheless, even the implementations of active teachers who voluntarily share their practice and participate in a competition seem to be lacking in certain key elements, such as assessment or the critique and revision phase. In addition, the results indicate and support earlier findings on the challenges teachers face when implementing PBL. The structural challenges reported in this and earlier 
studies (e.g. Viro et al., 2020; Mentzer et al., 2017) are hindering schools and teachers' efforts to implement PBL in integrated science education and should, therefore, be taken into account on a national level, when reforming curriculum or standards recommending integrated approaches such as PBL. Teachers can partly overcome the challenges relating to facilitating $\mathrm{PBL}$ with more experience and a deeper understanding of the PBL method. To this end, we have two recommendations. One, the academic discussion and research to further clarify the PBL design principles should continue to achieve a consensus on PBL as a method for integrated science teaching. For example, PBL design principles should address the content of learning to guarantee the inclusion of core concepts and skills of integrated subjects. Second, teachers need education programmes that support their pedagogical competence in executing PBL in integrated science education.

The results could be taken carefully into account in preparing teacher education for pre-service and in-service teachers. Without adequate attention to ways of supporting teachers, these innovative educational approaches will not be widely adopted (Blumenfeld et al., 1991; Mentzer et al., 2017). Integrated approaches such as PBL also require substantial changes in teachers' thinking about and dispositions toward classroom structures, activities, and tasks (Han et al., 2015). Furthermore, as it can take even two to three years for teachers to shift their understanding and learn to use PBL in practice (Mentzer et al., 2017), there is a need for developing long-term or even continuous and collaborative models for teacher education. Some teachers in StarT found collaborative learning and being a part of an international community professionally useful. Therefore, StarT in itself could be seen as a novel model for continuous teacher education programme in which:

1. Teachers' pedagogical development occurs while facilitating PBL and working together with the students, other teachers and other collaborators.

2. Teachers have access to tested models for PBL and good teaching practices from other teachers as well as online instructions and training.

3. Participating teachers and schools are a part of the StarT community, where learning is shared through workshops, science fairs and online voting for best projects as well as best teaching practices. 


\section{Acknowledgements}

The researchers would like to express their gratitude to the LUMA Centre Finland for the opportunity to gather data and conduct research as a part of the StarT programme. The research has been partly carried out under a grant from the Finnish Cultural Foundation.

\section{References}

Åström, M. (2008). Defining integrated science education and putting it to test [Doctoral dissertation, Linköping University]. Linköping University Electronic Press.

Beane, J. A. (1997). Curriculum integration: Designing the core of democratic education. Teachers College Press.

Bell, S. (2010). Project-based learning for the 21st century: Skills for the future. The Clearing House: A Journal of Educational Strategies, Issues and Ideas, 83(2), 39-43. https://doi.org/10.1080/00098650903505415

Bennett, J., Lubben, F., \& Hogarth, S. (2007). Bringing science to life: A synthesis of the research evidence on the effects of context-based and STS approaches to science teaching. Science Education, 91(3), 347-370. https://doi.org/10.1002/sce.20186

Blumenfeld, P. C., Soloway, E., Marx, R. W., Krajcik, J. S., Guzdial, M., \& Palincsar, A. (1991). Motivating project-based learning: Sustaining the doing, supporting the learning. Educational Psychologist, 26(3-4), 369-398. https://doi.org/10.1080/00461520.1991.9653139

Boss, S., \& Larmer, J. (2018). Project based teaching: How to create rigorous and engaging learning experiences. Association for Supervision \& Curriculum Development.

Braun, V., Clarke, V., \& Gray, D. (2017). Innovations in qualitative methods. In B. Gough (Ed.), The palgrave handbook of critical social psychology (pp. 243-266). Palgrave Macmillan UK. https://doi.org/10.1057/978-1-137-51018-1_13

Cohen, L., Manion, L., \& Morrison, K. (2007). Research methods in education (6th ed.). Taylor \& Francis.

Condliffe, B., Quint, J., Visher, M. G., Bangser, M. R., Drohojowska, S., Saco, L., \& Nelson, E. (2017). Project-based learning. A literature review -working paper. MDRC.

Czerniak, C. M., \& Johnson, C. C. (2014). Interdisciplinary science teaching. In S. K. Abell, \& N. G. Lederman (Eds.), Handbook of research on science education (pp. 395-411)

Drisko, J. W., \& Maschi, T. (2015). Content analysis. Oxford University Press.

Ertmer, P. A., \& Simons, K. D. (2006). Jumping the PBL implementation hurdle: Supporting the efforts of K-12 teachers. Interdisciplinary Journal of Problem-Based Learning, 1(1) https://doi.org/10.7771/1541-5015.1005

Finnish National Agency for Education [EDUFI] (2016). Perusopetuksen opetussuunnitelman perusteet 2014 (OPH määräykset ja ohjeet 2014:96). Next Print Oy.

https://www.oph.fi/fi/koulutus-ja-tutkinnot/perusopetuksen-opetussuunnitelmanperusteet\#6928a244

Habók, A., \& Nagy, J. (2016). In-service teachers' perceptions of project-based learning. Springerplus, 5(1), 1-14. https://doi.org/10.1186/s40064-016-1725-4

Han, S., Yalvac, B., Capraro, M. M., \& Capraro, R. M. (2015). In-service teachers' implementation and understanding of STEM project-based learning. EURASIA Journal of Mathematics, 
Science \& Technology Education, 11(1), 63-76.

https://doi.org/10.12973/eurasia.2015.1306a

Hasni, A., Bousadra, F., Belletête, V., Benabdallah, A., Nicole, M., \& Dumais, N. (2016). Trends in research on project-based science and technology teaching and learning at K-12 levels: A systematic review. Studies in Science Education, 52(2), 199-231.

https://doi.org/10.1080/03057267.2016.1226573

Kingston, S. (2018). Project based learning \& student achievement: What does the research tell us? (PBL evidence matters, volume 1, no. 1). Buck Institute for Education.

Kokotsaki, D., Menzies, V., \& Wiggins, A. (2016). Project-based learning: A review of the literature. Improving Schools, 19(3), 267-277. https://doi.org/10.1177/1365480216659733

Kolodner, J., Zham, B., \& Demery, R. (2015). Project-based inquiry science. In Sneider, C. I. (Ed.) The go-to guide for engineering curricula, grades 6-8: Choosing and using the best instructional materials for your students (pp. 122). SAGE Publications, Ltd. https://doi.org/10.4135/9781483385730.n11

Krajcik, J. S., \& Shin, N. (2014). Project-based learning. In R. K. Sawyer (Ed.), The Cambridge handbook of the learning sciences (pp. 275-297). Cambridge University Press. https://doi.org/10.1017/CBO9781139519526.018

LUMA Centre Finland. (n.d.). StarT - together for a good future. StarT. https://start.luma.fi/en/start-together-for-a-good-future

Lyons, T. (2020). Seeing through the acronym to the nature of STEM. Curriculum Perspectives, 4O(2), 225-231. https://doi.org/10.1007/s41297-020-00108-2

Marshall, J. A., Petrosino, A. J., \& Martin, T. (2010). Pre-service teachers' conceptions and enactments of project-based instruction. Journal of Science Education and Technology, 19(4), 370-386. https://doi.org/10.1007/s10956-010-9206-y

Mayring, P. (2014). Qualitative content analysis: Theoretical foundation, basic procedures and software solution. Klagenfurt: Social Science Open Access Repository. https://nbnresolving.org/urn:nbn:de:0168-ssoar-395173

Mentzer, G. A., Czerniak, C. M., \& Brooks, L. (2017). An examination of teacher understanding of project based science as a result of participating in an extended professional development program: Implications for implementation. School Science and Mathematics, 117(1-2), 7686. https://doi.org/10.1111/ssm.12208

National Research Council (2013). Next generation science standards: For states, by states. The National Academies Press. https://doi.org/10.17226/18290

Savery, J. R. (2019). Comparative pedagogical models of Problem-Based learning. The wiley handbook of Problem-Based learning (pp. 81-104). John Wiley \& Sons, Inc. https://doi.org/10.1002/9781119173243.ch4

Shwartz, Y., Weizman, A., Fortus, D., Krajcik, J., \& Reiser, B. (2008). The IQWST experience: Using coherence as a design principle for a middle school science curriculum. The University of Chicago Press. https://doi.org/10.1086/590526

Thomas, J. W. (2000). A review of research on project-based learning. San Rafael, CA: Autodesk Foundation.

Viro, E., \& Joutsenlahti, J. (2020). Learning mathematics by project work in secondary school. LUMAT: International Journal on Math, Science and Technology Education, 8(1) https://doi.org/10.31129/LUMAT.8.1.1372

Viro, E., Lehtonen, D., Joutsenlahti, J., \& Tahvanainen, V. (2020). Teachers' perspectives on project-based learning in mathematics and science. European Journal of Science and Mathematics Education, 8(1), 12-31. http://www.scimath.net/archive.asp 


\section{Appendix}

Appendix 1: The Elements of project-based learning (PBL) per case and examples of teaching practices related to the elements.

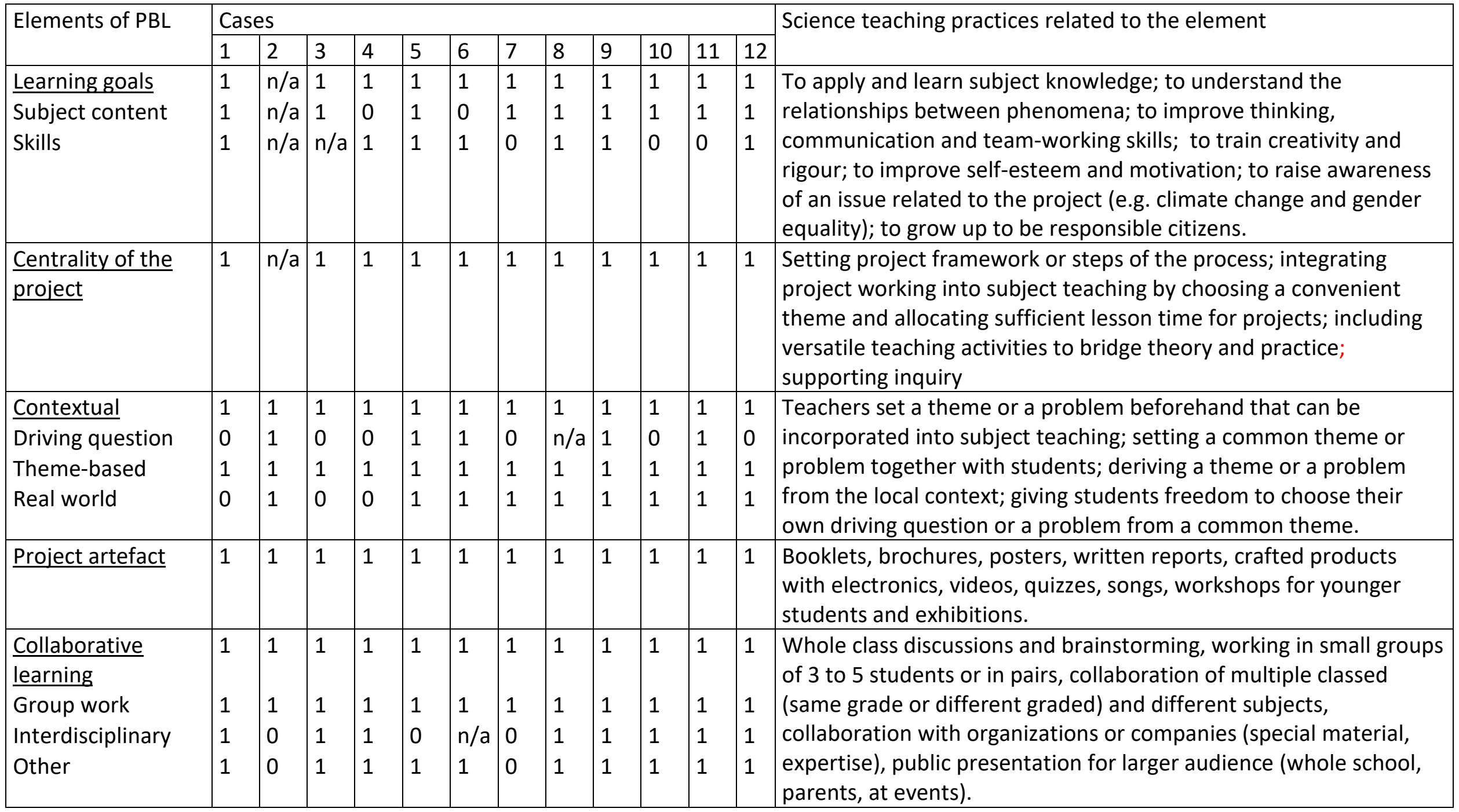




\begin{tabular}{|c|c|c|c|c|c|c|c|c|c|c|c|c|c|}
\hline $\begin{array}{l}\text { Constructive } \\
\text { Investigation } \\
\text { Critique and } \\
\text { revision }\end{array}$ & $\begin{array}{l}1 \\
1 \\
0\end{array}$ & $\begin{array}{l}1 \\
1 \\
0\end{array}$ & $\begin{array}{l}1 \\
1 \\
0\end{array}$ & $\begin{array}{l}1 \\
1 \\
0\end{array}$ & $\begin{array}{l}1 \\
1 \\
0\end{array}$ & $\begin{array}{l}1 \\
1 \\
0\end{array}$ & $\begin{array}{l}1 \\
1 \\
0\end{array}$ & $\begin{array}{l}1 \\
1 \\
1\end{array}$ & $\begin{array}{l}0 \\
0 \\
0\end{array}$ & $\begin{array}{l}1 \\
1 \\
1\end{array}$ & $\begin{array}{l}1 \\
0 \\
0\end{array}$ & $\begin{array}{l}1 \\
1 \\
1\end{array}$ & $\begin{array}{l}\text { Establishing the aim and tasks, gathering information by student } \\
\text { (using schoolbooks and online resources) or given by teachers or } \\
\text { outside experts (lectures, demonstrations, and assignments), } \\
\text { discussing and analysing the problem (within group, with teacher } \\
\text { and/or the whole class), students test possible solutions (building a } \\
\text { prototype, taking measurements), writing project diaries, making } \\
\text { mind-maps. }\end{array}$ \\
\hline $\begin{array}{l}\text { Student } \\
\text { engagement } \\
\text { Student-centred } \\
\text { Teacher-led }\end{array}$ & $\begin{array}{l}0 \\
1\end{array}$ & $\begin{array}{l}1 \\
0\end{array}$ & $\begin{array}{l}1 \\
1\end{array}$ & $\begin{array}{l}1 \\
1\end{array}$ & $\begin{array}{l}1 \\
1\end{array}$ & $\begin{array}{l}1 \\
0\end{array}$ & $\begin{array}{l}0 \\
1\end{array}$ & $\begin{array}{l}1 \\
1\end{array}$ & $\begin{array}{l}0 \\
1\end{array}$ & $\begin{array}{l}0 \\
1\end{array}$ & $\begin{array}{l}1 \\
1\end{array}$ & $\begin{array}{l}1 \\
0\end{array}$ & $\begin{array}{l}\text { Group formation by teachers or students; students involvement in } \\
\text { choosing a theme, aims, project artefact and how to work and } \\
\text { create the artefact varied from teacher-led to autonomous group } \\
\text { work by the students; often teachers set the frame for the project } \\
\text { and students work autonomously inside the frame. Teachers } \\
\text { engage students by discussions, brainstorming, activities (hands- } \\
\text { on, games or quizzes), participating in contests and study visits. }\end{array}$ \\
\hline $\begin{array}{l}\text { Scaffolding } \\
\text { instruction }\end{array}$ & 1 & $n / a$ & 0 & 1 & $n / a$ & $/ a$ & 0 & 1 & 1 & $\mathrm{n} / \mathrm{a}$ & 1 & 1 & $\begin{array}{l}\text { Diversifying learning assignments and projects, giving theory } \\
\text { lessons related to the project topic, setting the project phases and } \\
\text { schedule, guiding towards a source of information (books, online } \\
\text { material, experts), providing needed resources, asking guiding } \\
\text { questions, making it possible for students to help each other and } \\
\text { ask questions. }\end{array}$ \\
\hline $\begin{array}{l}\text { Assessment } \\
\text { Project artefact } \\
\text { Student reflection } \\
\text { Feedback }\end{array}$ & \begin{tabular}{|l|}
1 \\
$n / a$ \\
1 \\
$n / a$
\end{tabular} & $\begin{array}{l}n / a \\
n / a \\
n / a \\
n / a\end{array}$ & $\begin{array}{l}\text { n/a } \\
\text { n/a } \\
n / a \\
n / a\end{array}$ & \begin{tabular}{|l|}
1 \\
1 \\
1 \\
$\mathrm{n} / \mathrm{a}$
\end{tabular} & $\begin{array}{l}n / a \\
n / a \\
n / a \\
n / a\end{array}$ & $\begin{array}{l}n / a \\
n / a \\
n / a \\
n / a\end{array}$ & $\begin{array}{l}n / a \\
n / a \\
n / a \\
n / a\end{array}$ & \begin{tabular}{|l|}
1 \\
$n / a$ \\
1 \\
1
\end{tabular} & $\begin{array}{l}1 \\
n / a \\
1 \\
1\end{array}$ & \begin{tabular}{|l|}
$n / a$ \\
1 \\
$n / a$ \\
$n / a$
\end{tabular} & $\begin{array}{l}n / a \\
1 \\
n / a \\
n / a\end{array}$ & $\begin{array}{l}1 \\
1 \\
1 \\
1\end{array}$ & $\begin{array}{l}\text { Students reflect on their work (what was successful, what did not } \\
\text { work, what they learned) for example in project diaries or during } \\
\text { presentations. Presentations, class discussion and forms are used } \\
\text { as opportunities for peer and teacher feedback, school teachers } \\
\text { and other experts asked to evaluate project presentations, quizzes } \\
\text { relating to project theme, voting for best project artefacts, } \\
\text { participating in contest }\end{array}$ \\
\hline $\begin{array}{l}\text { Publicity } \\
\text { Public presentation } \\
\text { Public product }\end{array}$ & $\begin{array}{l}1 \\
1 \\
0\end{array}$ & $\begin{array}{l}1 \\
1 \\
0\end{array}$ & $\begin{array}{l}1 \\
1 \\
1\end{array}$ & $\begin{array}{l}1 \\
1 \\
0\end{array}$ & $\begin{array}{l}1 \\
1 \\
0\end{array}$ & $\begin{array}{l}1 \\
1 \\
1\end{array}$ & $\begin{array}{l}1 \\
1 \\
0\end{array}$ & $\begin{array}{l}1 \\
1 \\
0\end{array}$ & $\begin{array}{l}1 \\
1 \\
1\end{array}$ & $\begin{array}{l}1 \\
1 \\
0\end{array}$ & $\begin{array}{l}1 \\
1 \\
1\end{array}$ & \begin{tabular}{|l}
1 \\
1 \\
1
\end{tabular} & $\begin{array}{l}\text { Organizing fairs or exhibitions (school, library, local events) with } \\
\text { oral presentations, posters and stands to present the project and } \\
\text { artefact, oral presentations in classroom, building a website for } \\
\text { the project, making a short video and other online applications, } \\
\text { writing a magazine, making a brochure. }\end{array}$ \\
\hline
\end{tabular}

